Family Medicine and Community Health

\title{
Transforming a medical curriculum development into an education research
}

\author{
Chuan Zou (D) ,' Xiaoyang Liao ${ }^{2}$
}

To cite: Zou C, Liao X. Transforming a medical curriculum development into an education research. Fam Med Com Health 2019;7:e000214. doi:10.1136/fmch-2019-000214

Received 30 July 2019 Accepted 31 July 2019

\section{Linked}

https://doi.org/10.1136/ fmch-2019-000219

\section{Check for updates}

(C) Author(s) (or their employer(s)) 2019. Re-use permitted under CC BY-NC. No commercial re-use. See rights and permissions. Published by BMJ.

${ }^{1}$ Department of General Medicine, Chengdu Fifth People's Hospital, Chengdu, China

${ }^{2}$ Department of General Medicine, Sichuan University West China Hospital, Chengdu, China

Correspondence to Professor Xiaoyang Liao; liaoxiaoyang@sohu.com
To the editor

As family medicine educators and researchers in China, it was with a great anticipation we read the article of curriculum development framework by Jill Schneiderhan and Dobson. ${ }^{1}$ Because education of future general practitioner in China has become increasingly important, this paper is timely and instructive. However, an elaborate curriculum development isn't sufficient to become an education research. We hope to raise some concerns for the education researchers regarding the methodological aspects while developing a curriculum.

It seems that some authors view education research as a 'soft' science, therefore conducting the research without adequate rigour and precision. A systematic review ${ }^{2}$ of experimental studies in medical education demonstrated generally poor quality with inexplicit study design statement, lack of comparison group and institutional review board approval. Another scoping review $^{3}$ of education researches in family medicine also highlights an overall need for increased sophistication in methodological approaches; $23 \%$ of the quantitative studies used pretests/post-tests, nearly half employed surveys as their primary method of data collection and only $10 \%$ used a randomised controlled trial. Taking the ubiquitous single-group pretests/ post-tests designs as an example, pretest will influence performance on an identical post-test through familiarity with the questions. Likewise, without a concurrent control group, positive result of such educational experiment doesn't signify the effectiveness of novel education intervention, as people spend time learning, they will receive higher scores on the post-training test. It also cannot justify the effectiveness compared with other existing teachings, therefore does little to inform educational practice. Such design is susceptible to numerous validity threats and has limited generalisability and application. ${ }^{4}$ Cook and Beckman ${ }^{4}$ also summarised other important yet often neglected issues in designing educational research.

As the field of medical education in family practice grows dramatically and the evolution from opinion-based teaching to evidencebased teaching, research in medical education matters with the premise of rigorous methodology. ${ }^{5}$ The perspective of education research should be changed from 'soft' to 'hard' science. We suggest the novice to follow the five steps proposed by William Ventres ${ }^{6}$ to start your education research, carefully design your investigation by obeying the evaluating guidelines ${ }^{7}$ from British Medical Journal or appraise your methodological quality by applying some valid scales, such as the Medical Education Research Study Quality Instrument. ${ }^{8}$ It would also be beneficial for the first-time researchers to attend some programmes that designed to build capacity for medical education research. ${ }^{9}$ Another convenient method could be the better engagement of methodologists throughout the research process.

Methodological aspects should be embedded in medical curriculum development with the simultaneous purpose of conducting education research. Paying more attention to methodology will bring better quality and combination of art and science in medical education.

Competing interests None declared.

Patient consent for publication Not required.

Provenance and peer review Not commissioned; internally peer reviewed.

Open access This is an open access article distributed in accordance with the Creative Commons Attribution Non Commercial (CC BY-NC 4.0) license, which permits others to distribute, remix, adapt, build upon this work non-commercially, and license their derivative works on different terms, provided the original work is properly cited, appropriate credit is given, any changes made indicated, and the use is non-commercial. See: http://creativecommons.org/licenses/by-nc/4.0/.

ORCID iD

Chuan Zou http://orcid.org/0000-0001-5094-3486 


\section{REFERENCES}

1 Jill Schneiderhan TCG, Dobson ML. Curriculum development: a how to primer. Fam Med Com Health 2019;7:e000046.

2 Cook DA, Beckman TJ, Bordage G. Quality of reporting of experimental studies in medical education: a systematic review. Med Educ 2007;41:737-45.

3 Webster F, Krueger P, MacDonald H, et al. A scoping review of medical education research in family medicine. BMC Med Educ 2015;15:79.

4 Cook DA, Beckman TJ. Reflections on experimental research in medical education. Adv Health Sci Educ Theory Pract 2010;15:455-64.

5 Harden RM, Grant J, Buckley G, et al. BEME guide No. 1: best evidence medical education. Med Teach 1999;21:553-62.
6 William Ventres LW-M. Getting started in research redefined: five questions for clinically focused physicians in family medicine. Family medicine and community health 2019;7:e000017.

7 Education Group for Guidelines on Evaluation. Guidelines for evaluating papers on educational interventions. BMJ 1999;318:1265-7.

8 Cook DA, Reed DA. Appraising the quality of medical education research methods: the medical education research study quality instrument and the Newcastle-Ottawa Scale-Education. Acad Med 2015;90:1067-76.

9 Archibald D, Hogg W, Lemelin J, et al. Building capacity for medical education research in family medicine: the program for innovation in medical education (PIME). Health Res Policy Syst 2017;15. 